\title{
Dynamics of an atomical-morphological parameters of plants of miscanthus got from culture in vitro at cultivation in open ground
}

\author{
Roik M. ${ }^{1}$, Kotsar M. ${ }^{2}$ \\ Institute of biopower cultures and sugar beet of NAAS, Clinichna Str., 25, Kyiv, 03141, Ukraine; e-mail: \\ 'sugarbeet@ukr.net, ${ }^{2}$ marichka.899@gmail.com
}

The purpose. To determine dynamics of anatomical-morphological parameters of miscanthus sprouts got from culture in vitro at cultivation the open ground. Methods. Technique of clonal microduplication of miscanthus (2013) is used, biometric, statistical. Results. Survival factor of plants of miscanthus is established for different genotypes from culture in vitro in conditions of open ground, as well as dynamics of anatomical-morphological parameters of miscanthus of different genotypes got from culture in vitro in conditions of cultivation in conditions in vivo within 3 years of vegetation without entering mineral fertilizers on light grey wood subacidic soil $(\mathrm{pH}=5,4)$ at regular irrigation. The first anatomical-morphological parameters at plants of miscanthus were determined in 3 months of vegetation after planting. They estimated key parameters of growth and development of plants of miscanthus in system of economicvaluable attributes - components of efficiency. For three years of cultivation of miscanthus they observed increase in amount of shoots on the average from 16 up to 41 pieces, in height of plants - from 92,8 up to $181,8 \mathrm{~cm}$, in area of sheet surface - from 31,8 up to $93,5 \mathrm{~cm}^{2}$. Genotypes of miscanthus with intensive increase of structural elements of biomass are allocated. Efficiency of methods of biotechnology for getting qualitative planting material of miscanthus is estimated. Conclusions. Survival factor for sprouts of miscanthus of different genotypes got from culture in vitro in conditions of field experiment varies within the limits of $79-98 \%$. For 3 years of cultivation of plants of miscanthus of six genotypes from collection of the institute of various origin got from culture in vitro form on the average $30-49$ shoots in height of $100,2-$ $241,8 \mathrm{~cm}$. The greatest intensive increase of amount of shoots, height of plants, amount of leaves and area of sheet surface on test field "Batyieva Hora" of the institute were characterized for genotypes of kinds $M$. giganteus, M. sinensis, M. sinensis Early. Use of methods of biotechnology enables to receive qualitative planting material of miscanthus for growing biopower plantations in conditions of Forest-steppe of Ukraine.

Key words: miscanthus, in vitro, sprouts, anatomical-morphological parameters, survival factor.

https://doi.org/10.31073/agrovisnyk201809-06

\section{Introduction}

In Ukraine, bioenergy is one of the strategic directions for the development of the renewable energy sector, given the high dependence of the country on imported energy sources and the high potential of biomass available for energy production [1]. Bioenergy crops are used for the production of thermal energy, cellulose and lignocellulose [2,3]. One of these crops is miscanthus, which on most of Ukraine's land areas can have a significant effect both on the amount of biomass and on the lowest cultivation costs [4]. Miscanthusis a long-term cereal crop that has been grown for many years in America and Western Europe as a source of bioenergy, due to high yield of dry biomass (up to $25 \mathrm{t} / \mathrm{ha}$ ), high calorific value (5 kW/h/kg or $18 \mathrm{MJ} / \mathrm{kg}$ ), low natural moisture content of stems at harvest time (up to $25 \%$ ). Miscanthus is the most efficient plant for solid biofuel production compared to other crops [5]. The increased demand for the cultivation of miscanthus in different regions and countries requires rational yield of planting material through biotechnology [6]. The genetic stability of isolated clones is observed even after many passages, which opens up great opportunities for reproduction and preservation of the gene pool of the species [7]. These methods allow receiving healthy planting material in large amount in a short period of time [8]. Miscanthus in vitro has quite high endurance in the winter period in northern Ukraine [9]. An important and rather complicated step is the adaptation of cloned seedlings from in vitro conditions to open ground. The dynamics 
of development of plants of the miscanthus, obtained from culture in vitro, under conditions of open soil experiment has been studied to a small extent.

Purpose. To determine of dynamics anatomical and morphological parameters of miscanthus seedlings in vitro for growing in open soil.

\section{Materials and methods}

The research was conducted in the sector cell culture and tissue culture in vitro and in the research field of the Institute for Bioenergy Crops and Sugar Beet "BatyievaHora" in 2013-2015.

The source material was the plants of the various species of miscanthus: $M$. giganteus $(3 x=57), M$. sinensis $(2 n=38), M$. sinensis Early $(2 n=38), M$. sacchariflorus $(2 n=38), M$. sinensis Late $(2 n=38), M$. sinensis New $(2 n=38)$ obtained by the method of clonal micropropagation.

The clonal micropropagation has been applied of miscanthusto the planting material. Six passages of cloning of introduced explants (seeds, buds from rhizomes) on the Murashige and Skoog medium were introduced into the culture. Plants with a developed root system (2-6 roots) with shoot height of 5-6 cm were planted in open soil directly from culture in vitro (without acclimatization) and covered with protective caps. The cultivation of miscanthusplants was carried out without the introduction of mineral fertilizers on light gray forest slightly acidic soil $(\mathrm{pH}=5.4)$, under the conditions of regular irrigation.

Anatomic and morphological parameters of miscanthusplants were determined at the end of the growing season of each year.

The obtained results were processed in accordance with generally accepted methods [10].

\section{Results}

Field experiment showed that survival plants from culture in vitro was quite high at direct transfer to the soil. The index of survival of miscanthusseedlings for this method of plant transfer was $91.0 \%$ on average with genotype fluctuations as following: M. giganteus - 79.0, M. sinensis Late - 93.0, M. sinensis Early - 88.0, M. sinensis - 98.0, M. sinensis New - 93.0 and M. sacchariflorus - $93 \%$ of adapted plants (Fig. 1).

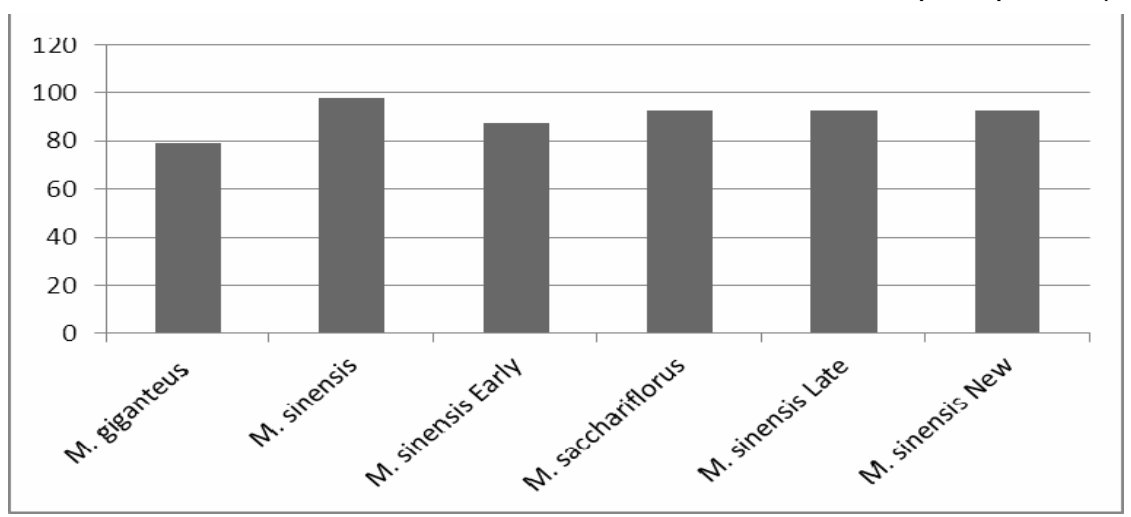

Fig. 1 Index of survival of different genus of miscanthus, $\%$

Shownin Fig. 2 are the miscanthusplants after one week and four weeks of growing in open soil. 


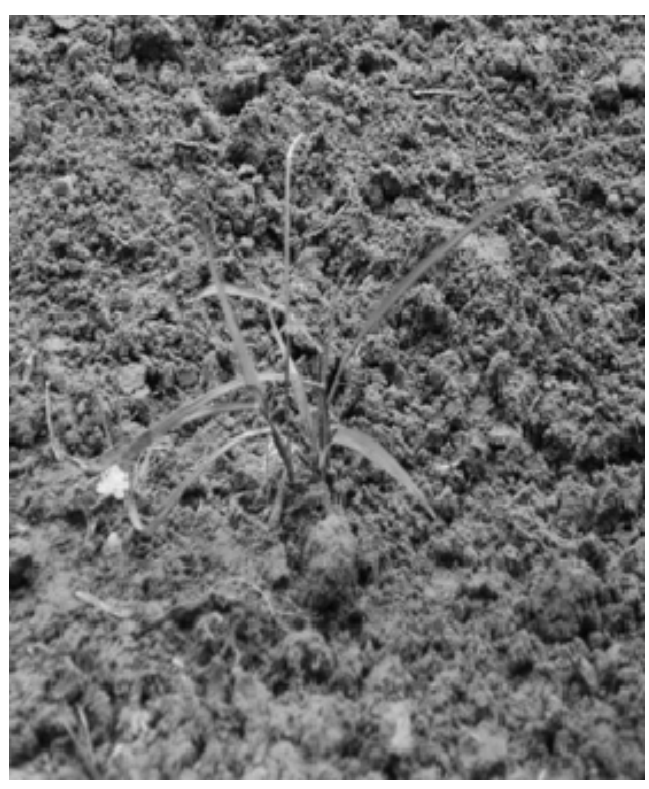

a)

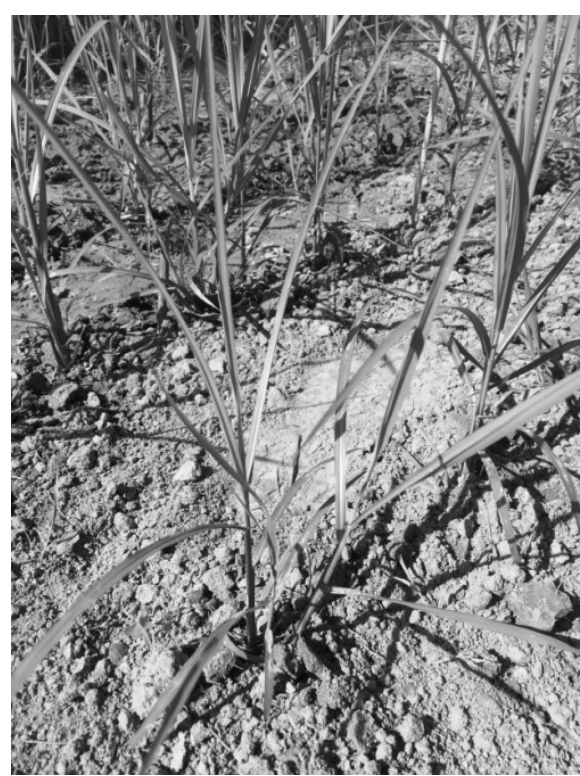

b)

Fig. 2 Plants of $M$. giganteusafter one week (a) and four weeks ofgrowing in open soil

The first anatomical and morphological parametersofmiscanthusplants were determined following three months after planting, the main parameters of the growth and development of miscanthus in terms of agronomicfeatures (components of productivity) were evaluated.

The number of shoots in the first year of vegetation was 10-23 depending on the genus of miscanthus (Table). In the second year, this indicator increased by 4-20 compared to the first year and varied a range of the 18-40. In the third year of vegetation, the number of shoots varied with a range of 30-49, that is, in three years each genotype increased thisparameters by 13-38 shoots The largest growth of shoots was observed in M. giganteus - from 11 to 49 shoots.

Table

Anatomic and morphological parameters of miscanthus in the open soil, IBC\&SB BatyievaHora, 20132015.

\begin{tabular}{|c|c|c|c|c|c|c|c|c|c|c|c|c|c|}
\hline \multirow{2}{*}{$\mathrm{N}$} & \multirow{2}{*}{$\begin{array}{l}\text { Genotypes of } \\
\text { miscanthus }\end{array}$} & \multicolumn{3}{|c|}{$\begin{array}{c}\text { Number of } \\
\text { shoots }\end{array}$} & \multicolumn{3}{|c|}{ Plant height $(\mathrm{cm})$} & \multicolumn{3}{|c|}{$\begin{array}{l}\text { Number of } \\
\text { leaves }\end{array}$} & \multicolumn{3}{|c|}{ Leaf area, $\mathrm{cm}^{2}$} \\
\hline & & $\stackrel{m}{\grave{N}}$ & $\stackrel{⿱ 亠 乂}{\circ}$ & $\frac{n}{\stackrel{N}{\circ}}$ & $\frac{m}{\stackrel{\infty}{\sim}}$ & $\stackrel{+}{\circ}$ & $\frac{n}{\grave{N}}$ & $\stackrel{m}{\stackrel{N}{N}}$ & $\stackrel{+}{\grave{N}}$ & $\frac{10}{\delta}$ & $\frac{m}{\grave{N}}$ & $\stackrel{+}{\grave{N}}$ & $\frac{n}{\grave{N}}$ \\
\hline 1 & M. giganteus & 11 & 18 & 49 & 84.8 & 198.4 & 241.8 & 10 & 11 & 13 & 28.0 & 82.5 & 113.3 \\
\hline 2 & M. sinensis & 23 & 29 & 40 & 126.6 & 160.5 & 170.3 & 8 & 10 & 11 & 40.3 & 78.0 & 94.7 \\
\hline 3 & $\begin{array}{l}\text { M. sinensis } \\
\text { Early }\end{array}$ & 12 & 27 & 39 & 94.8 & 179.8 & 182.5 & 8 & 10 & 11 & 41.7 & 98.0 & 110.9 \\
\hline 4 & $\begin{array}{l}\text { M. saccharifl } \\
\text { orus }\end{array}$ & 17 & 21 & 30 & 65.4 & 95.6 & 100.2 & 6 & 8 & 8 & 26.0 & 58.5 & 78.3 \\
\hline 5 & $\begin{array}{l}\text { M. sinensis } \\
\text { Late }\end{array}$ & 10 & 24 & 41 & 74.8 & 160.2 & 173.8 & 8 & 8 & 10 & 31.7 & 75.9 & 85.2 \\
\hline 6 & $\begin{array}{l}\text { M. sinensis } \\
\text { New }\end{array}$ & 20 & 40 & 49 & 110.5 & 142.6 & 222.4 & 8 & 8 & 10 & 23.3 & 26.1 & 78.8 \\
\hline & Medium & 16 & 27 & 41 & 92.8 & 156.2 & 181.8 & 8 & 9 & 11 & 31.8 & 69.8 & 93.5 \\
\hline
\end{tabular}

The height of miscanthusplants in the three months of the first year of vegetation varied with a range of 65.4-126.6 $\mathrm{cm}$. During the second year of vegetation, the height of plants in different genotypes was 95.6$198.4 \mathrm{~cm}$, with the difference compared to the first year of vegetation of $30.2-113.6 \mathrm{~cm}$. During the three years of vegetation, the maximum height was recorded in $M$. giganteus $-241.8 \mathrm{~cm}$, the minimum in $M$. 
sacchariflorus - $100.2 \mathrm{~cm}$. In other miscanthusgenotypes, the height of the plants varied with a range of $170.3-222.4 \mathrm{~cm}$ and a difference to the first year of vegetation of $34.8-157.0 \mathrm{~cm}$.

The number of leaves in the first year of vegetation in all genotypes was 610 . In the second year, thisparameters increased on the average of two leaves. In the third year of vegetation, the difference in the number of leaves differed by $2-3$, that is, in all genotypes, this parameters was $8-13$ (the average parameters was 11 leaves).

The leaf area index also varies depending on the genotype. During the first year of vegetation, thisparameters varied within the range of $23.3-41.7 \mathrm{~cm}^{2}$, for the second year $-26.1-98.0 \mathrm{~cm}^{2}$ with a difference to the first year of 2.8-56.3 $\mathrm{cm}^{2}$. In the third year, the largest leaf area index was in M. giganteus $113.3 \mathrm{~cm}^{2}$ and $M$. sinensis Early $-110.9 \mathrm{~cm}^{2}$ with a difference to the first year, 85.3 and $69.2 \mathrm{~cm}^{2}$, respectively. Such genotypes as $M$. sinensis, M. sacchariflorus, $M$. sinensis Late and $M$. sinensis New increased leaf area index by $50 \mathrm{~cm}^{2}$ with a fluctuation of $78.3-94.7 \mathrm{~cm}^{2}$.

Shownin Fig. 3 is the appearance of $M$. sinensis from culture in vitroafter the first three months of the first year and after the third year of vegetation.

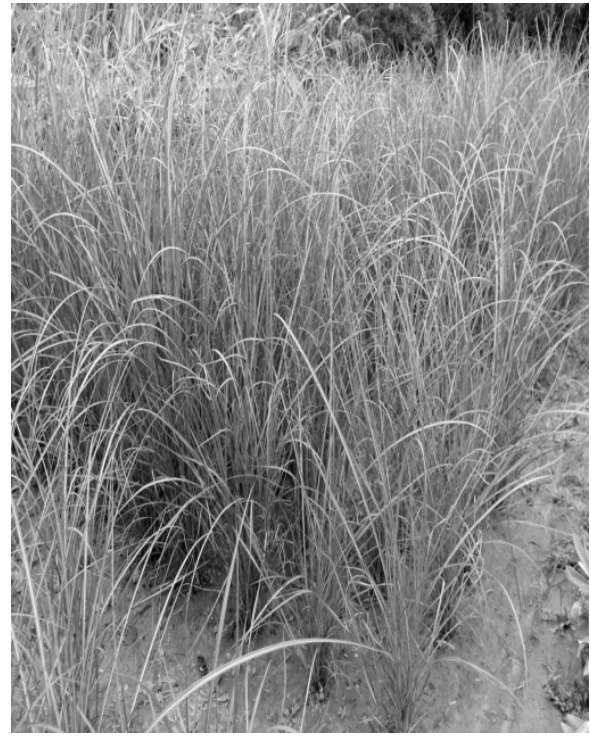

a)

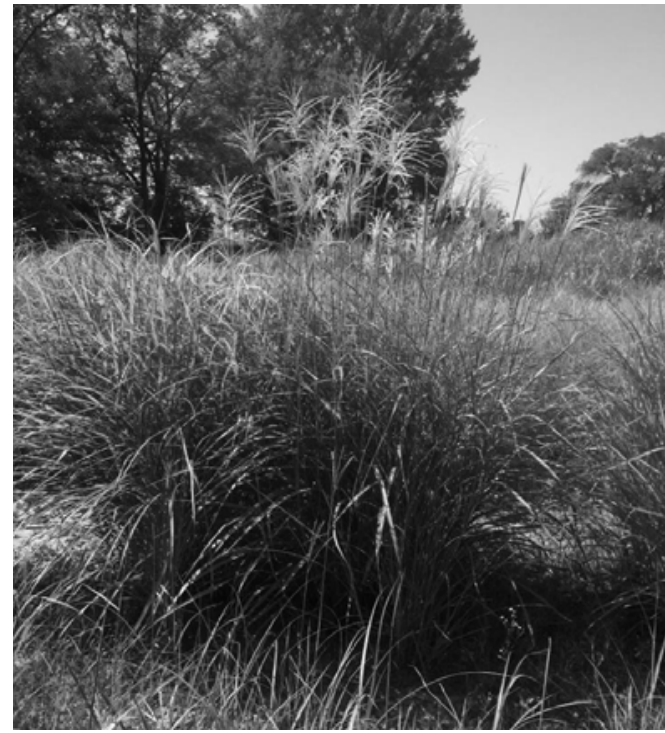

b)

Fig. 3 Plants of $M$. sinensis from culture in vitro in the first (a) and the third (b)year of vegetation

Starting from the second year of miscanthusvegetation, there were blossoms of some individual plants of different species, and in the third year of vegetation their mass flowering was observed.

Miscanthus reveals its bioenergy potential in terms of anatomic and morphological parameters starting from the third years of vegetation, which allows utilization of biomass for the needs of bioenergy.

\section{Conclusions}

The index of survival of the miscanthus seedlings of different genotypes when transferred from culture in vitro intoopen soil experiment varied within a range of $79-98 \%$.

For first three years of growing miscanthusplants of six genotypes from the IBC\&SB's collection form an average of 30-49 shoots with a height of $100.2-241.8 \mathrm{~cm}$.

The genotypes of the species $M$. giganteus, $M$. sinensis, $M$. sinensis Early demonstrated the most intensive increase in the number of shoots, plant height, number of leaves and leaf area in the experimental field of the IBC\&SB "BatyievaHora".

The use of biotechnology methods allows obtaining high-quality planting material of miscanthus for bioenergy plantations of the Forest-Steppe of Ukraine.

\section{References}

1. Roik M.V., Yaholnyk O.O. (2014). Bioenerhetyka yak nauka y haluz ekonomiky: istoriia, kontseptsiia, periodyzatsiia (etapy) rozvytku. [Bioenergy as a science and branch of economy: history, concept, periodization (stages) of development]. Bioenerhetyka. №1 (3). P. 7-11. [in Ukrainian]. 
2. McLaughlin S.B., Walsh M.E. (1998) Evaluating environmental consequences of producing herbaceous crops for bioenergy. Biomass Bioenergy. Vol. 14. P. 317-324.

3. Khanna M., Dhungana B., Clifton-Brown J. (2008) Costs of producing miscanthus and switchgrass for bioenergy in Illinois. Biomass and Bioenergy. Vol. 32, Issue 6. P. 482-493.

4. Los L.V., Zinchenko V.O., Zhaivoronovskyi V.R. (2011). Vyroshchuvannia i hazyfikatsiia biopalyv efektyvnyi shliakh vyrishennia «enerhetychnykh» i ekolohichnykh problem na prykladi miskantusa hihanteusa. [Cultivation and gasification of biofuels are an effective way to solve "energy" and environmental problems on the example of the Miskanthus giantheus]. Visnyk ZhNAEU. № 2. P. 46-57. [in Ukrainian].

5. Humentyk M.Ya. (2010). Perspektyvy vyroshchuvannia bahatorichnykh zlakovykh kultur dlia vyrobnytstva biopalyva. [Prospects for growing perennial crops for production biofuels]. Tsukrovi buriaky. № 4. P. 21-22. [in Ukrainian].

6. Kim H.S., Zhang G., Juvik J.A., Widholm J.M. (2010). Miscanthus giganteus plant regeneration: effect of callus types, ages and culture methods on regeneration competence. GCB Bioenergy. Vol. 2. P. 192-200.

7. Roik M.V., Kornieieva M.O. (2015) Napriamy, metody ta stratehiia rozvytku selektsii. [Areas, methods and strategy of breeding development]. Tsukrovi buriaky. № 6. P. 7-9. [in Ukrainian].

8. Govil S., Gupta S.C. (1997). Commercialization of plant tissue culture in India. Plant cell, tissue and organ culture. Vol. 51. P. 65-73.

9. Bekh N.S., Kotsar M.O. (2016) Klonalne mikrorozmnozhennia miskantusu, yak sposib otrymannia posadkovoho materialu. [Clonal Microcropping of the Miscanthus, as a way of obtaining a landing material]. Bioenerhetyka. № 1 (7). P. 26-28. [in Ukrainian].

10. Dospekhov B.A. (1985) Metodyka polevoho oputa. [Field experience]. Moskva: Ahropromyzdat,. 351 p. [in Russian]. 